\title{
India in the 1980s and 1990s: A Triumph of Reforms
}

\author{
Arvind Panagariya*
}

November 6, 2003

\footnotetext{
* The author is a Professor of Economics at University of Maryland, College Park, MD 20742. Email: panagari@econ.umd.edu. I have greatly benefited from comments by Jagdish Bhagwati, Rajesh Chadha, Satish Chand, Douglas Irwin, Raghav Jha, Vijay Joshi, Ashoka Mody, Jayanta Roy, Ratna Sahay, Kunal Sen, N.K. Singh, T.N. Srinivasan and Roberto Zagha on an earlier draft.
} 


\section{Introduction}

While public opinion in India continues to move towards the view that liberalization has been good, that more of it is needed, and that its pace must be accelerated, the view among some scholarly and policy circles has turned skeptical. It is being argued that in the 1980s, well before the launch of the July 1991 reforms, annual GDP growth rate had hit the 5.6 percent mark. Moreover, growth rate in the 1990s was not much higher. Therefore, liberalization cannot be credited with having made a significant difference to growth. ${ }^{1}$

The key contribution expressing this skepticism has come from economic historian J. Bradford DeLong (2001, pp. 5-6) who writes in an article on growth in India: "What are the sources of India's recent acceleration in economic growth? Conventional wisdom traces them to policy reforms at the start of the $1990 \mathrm{~s} .$. Yet the aggregate growth data tells us that the acceleration of economic growth began earlier, in the early or mid-1980s, long before the exchange crisis of 1991 and the shift of the government of Narasimha Rao and Manmohan Singh toward neoliberal economic reforms."

DeLong (2001, p. 6) continues:

"Thus apparently the policy changes in the mid- and late-1980s under the last governments of the Nehru dynasty were sufficient to start the acceleration of

\footnotetext{
${ }^{1}$ While the documentation below is limited to scholarly writings, many opponents of reforms in the political arena, including some in the Congress party, share this view.
} 
growth, small as those policy reforms appear in retrospect. Would they have just produced a short-lived flash in the pan--a decade or so of fast growth followed by a slowdown--in the absence of the further reforms of the 1990s? My hunch is that the answer is 'yes.' In the absence of the second wave of reforms in the 1990s it is unlikely that the rapid growth of the second half of the 1980s could be sustained. But hard evidence to support such a strong counterfactual judgment is lacking." [Emphasis added.]

The paper by DeLong appears in a volume edited by Dani Rodrik. Summarizing the main message of the paper in the introduction to the volume, Rodrik (2002) carries DeLong's skepticism to the next level. He notes,

"How much reform did it take for India to leave behind its 'Hindu rate of growth' of three percent a year? J. Bradford DeLong shows that the conventional account of India, which emphasizes the liberalizing reforms of the early 1990s as the turning point, is wrong in many ways. He documents that growth took off not in the $1990 \mathrm{~s}$, but in the $1980 \mathrm{~s}$. What seems to have set off growth were some relatively minor reforms. Under Rajiv Gandhi, the government made some tentative moves to encourage capital-goods imports, relax industrial regulations, and rationalize the tax system. The consequence was an economic boom incommensurate with the modesty of the reforms. Furthermore, DeLong's backof-the-envelope calculations suggest that the significantly more ambitious reforms of the 1990s actually had a smaller impact on India's long run growth path. DeLong speculates that the change in official attitudes in the 1980s, towards 
encouraging rather than discouraging entrepreneurial activities and integration into the world economy, and a belief that the rules of the economic game had changed for good may have had a bigger impact on growth than any specific policy reforms."

It is not entirely clear as to what policy message is to be gleaned from this skepticism. Neither DeLong nor Rodrik suggests that the reforms of 1990s were detrimental to the growth process. DeLong explicitly states that in the absence of the second wave of reforms in the 1990s, it is unlikely that the rapid growth of the second half of the 1980s could have been sustained. Rodrik is more tentative, emphasizing the change in official attitudes over the change in policies, possibly implying that the attitudes having changed for good, growth would have sustained even without the reforms of 1990s.

This interpretation itself raises two immediate questions: Is there evidence demonstrating that official attitudes changed significantly during 1980s and if so how was this change conveyed to the public? Most observes of India are likely to question the view that there had been a significant shift in official attitudes in the 1980s. Indirect evidence of the general dominance of the old attitudes can be found in the care Manmohan Singh took in packaging the bold reforms of 1991, describing them as a continuation of the old policies. A careful reader of Singh's historic 1991 budget speech is struck by the effort he made to draw a close connection between his proposals and the policies initiated by India's first Prime Minister Jawaharlal Nehru and carried forward by his grandson Rajiv Gandhi. As I noted in Panagariya (1994), Singh continuously 
reiterated the usefulness of the past policies in the speech and repeatedly referred to the contributions of Nehru to development, while also recalling the just-assassinated former Prime Minister Rajiv Gandhi's dream of taking India into the $21^{\text {st }}$ century.

More directly, reacting to a previous draft of this paper, N.K. Singh who has been directly involved in policy making in India during 1980s as well as 1990s and is currently a Member, Planning Commission wrote the following in personal correspondence:

"I am somewhat intrigued by the statement of Delong \& Rodrik stressing change in official attitude over change in policies implying that if attitude changed for good, growth would have been sustained even without reforms in the 1990s. Even today, more than change in policies we are struggling with change in attitude. The first reflex of any observer of Indian economy or potential foreign investor would be that while policies may not be so bad it is the attitude particularly of official ones which becomes the Achilles heel. In fact the 80s and even the 90s have seen far-reaching change in policies which have not translated themselves fully into changes in attitudes. This attitudinal change indeed constitutes a major challenge in our reform agenda."

But even conceding that a change in attitude on the part of officials had taken place, one must confront the question how officials could have conveyed this change to entrepreneurs without a change in the policy or its implementation? It is only through policy changes such as the expansion of the Open General Licensing list at the expense of the banned and restricted import licensing lists and change in the implementation strategy as, for instance, by issuing import licenses more liberally that officials could convey the 
change in their attitudes to entrepreneurs. By extension, the absence of further reforms would have surely signaled to entrepreneurs a reversion back to the old attitudes.

The policy versus attitude change issue apart, the key question is whether minor changes in either policy or attitudes in the 1980s produced the same outcome as the major reforms in the 1990s. In this paper, I demonstrate that the skeptical view offered by Rodrik and DeLong overstates the growth and understates the reforms during 1980s. Growth during 1980s was fragile, highly variable across years, and unsustainable. In contrast, once the 1991 reforms took root, growth became less variable and sustainable with even a slight upward shift in the mean growth rate.

At the same time, reforms played a significant role in spurring growth in 1980s. The difference between the reforms in 1980s and those 1990s is that the former were limited in scope and without a clear roadmap whereas the latter were systematic and systemic. $^{2}$ This said the reforms in 1980s must be viewed as precursor to those in 1990s rather than a part of the isolated and sporadic liberalizing actions during1960s and 1970s, which were often reversed within a short period. The 1980s reforms proved particularly crucial to building internal support for future liberalization and imparting confidence to politicians in the ability of policy changes such as devaluation, trade liberalization and de-licensing of investment to spur growth without disruption. It is questionable, for

\footnotetext{
2 This is not unlike the stop-go reforms in China though the latter did go much farther during 1980s, especially in the Special Economic Zones and Open Cities.
} 
example, whether the July 1991 package would have been politically acceptable in the absence of the experience and confidence in liberal policies acquired during 1980s.

Before I move to the next section, let me note that the view that liberal economic policies did not make a significant contribution to the shift in growth during 1980s extends well beyond reforms skeptics and includes some of the ardent advocates of reforms. ${ }^{3}$ Joshi and Little (1994, chapter 13), who have been champions of reforms and have extensively studied Indian macroeconomic policies in the 1980s attribute the high growth during this period to the fiscal expansion financed by external and internal borrowing. ${ }^{4}$ This is also the view expressed indirectly by Ahluwalia (2002, p. 67) who states that while growth record in the 1990s was only slightly better than in the 1980s, the 1980s growth was unsustainable, "fuelled by a build up of external debt that culminated in the crisis of 1991." Srinivasan and Tendulkar (2003) attribute some role to the reforms but they too underplay them when they state:

"India's exports increased over this period [1980s] of piecemeal reforms, but this was more due to a real exchange rate depreciation mostly as a result of exogenous forces than due to an active policy of nominal devaluation or due to explicit policy

3 Among skeptics, Joseph Stiglitz too seems to have bought into the DeLong-Rodrik story. Thus, in an exchange with economist Kenneth Rogoff published in the Wall Street Journal Europe (October 18, 2002), he is reported to have said, "The two countries that have the most impressive economies now are China and India. They happen to be the two that bought the least into the globalization story that the IMF and others are selling."

${ }^{4}$ Vijay Joshi has recently changed his mind, however. Thus, commenting on an earlier draft of this paper, he writes in personal correspondence, "Joshi and Little did point to the importance of the mildly liberalizing reforms in the 1980s but in retrospect we should have put greater stress on them exactly as you have done." 
reforms aimed at reducing trade barriers. Growth performance was also distinctly better in the 1980s than in the earlier period. This surge in growth, however, was supported on the demand side by unsustainable fiscal policies, and it ended with an economic crisis in 1991.’[Emphasis added.]

Finally, Das (2000), as quoted by DeLong, gives the strongest impression of all writers that reforms originated with the July 1991 package announced by Manmohan Singh: “...in July $1991 \ldots$ with the announcement of sweeping liberalization by the minority government of P.V. Narasimha Rao... opened the economy... dismantled import controls, lowered customs duties, and devalued the currency... virtually abolished licensing controls on private investment, dropped tax rates, and broke public sector monopolies.... [W]e felt as though our second independence had arrived: we were going to be free from a rapacious and domineering state..."

Among those who have ventured to attribute the acceleration in growth in the 1980s to liberalization are Desai (1999), Pursell (1992) and Virmani (1997). Desai focuses on liberalization in the industry and industrial growth and Pursell on trade liberalization during this decade. I draw on their work later, particularly the latter. The discussion in Virmani is brief but he attributes the shift in the growth rate in the 1980 s virtually entirely to liberalization. Moreover, he views the liberalization during 1980s and 1990s as "sub-phases" of an overall phase. In contrast, the view taken here is that the liberalization in the 1980s laid down the groundwork that helped carry out systemic and systematic reforms in the 1990s. 
The remainder of the paper is organized as follows. In Section 2, I contrast the experience during 1980s with that in 1990s, arguing that growth in the former period was fragile and unsustainable. In Section 3, I link the shift in the growth rate in the 1980 s to the conventional economic reforms both in terms of the policy changes and outcomes. In Section 4, I discuss the role played by expansionary fiscal policies supported by both internal and external borrowing that made the growth process unsustainable. In Section 5, I sum up the main arguments of the paper. Finally, in Section 6, I offer remarks on why India has remained behind China and what it will take to produce a growth rate in India comparable to that of the latter.

\section{The Fragility of Growth in the 1980s}

I will argue below that the main reason why the average growth rate during 1980s looks comparable to that in the 1990s is the quantum jump in the average growth rate during 1988-91. But as a starting point, it worth noting that contrary to the consensus view, which traces the initial growth spurt to early 1980s, faint signs of a shift in the growth rate can be seen starting in the late 1970s. Thus, consider Table 1, which documents the average annual growth rates of Gross Domestic Product (GDP) at factor cost according to the five-year plan periods as well as by decades.

If we consider growth rates according to the plans, the first major break from the Hindu rate of growth occurs during the Fifth Five Year Plan (1974-79) with the growth rate reaching 4.9 percent per annum. This was in comparison to 3.6 percent annual 
growth during the preceding 23 years taken together and the best prior performance of 4.3 percent during the Second Five Year Plan (1956-61). On the other hand, if we go by growth rates over decades (see the second half of Table 1), the break in performance occurs during 1980s with GDP growing at 5.6 percent annually during 1981-91.

But both of these observations are misleading. To identify the break in the performance more sharply and relate it to changes in policies, we must begin by examining the growth rates in individual years. This is done in Table 2 where I present growth rates in individual years starting with 1969-70, the first year of the Fourth FiveYear Plan. In the last two columns of this table, I show the averages of growth rates during the five and ten years ending with the year shown, respectively. ${ }^{5}$

Two important facts can be gleaned from Table 2. First, the earliest break in the growth rate occurs in 1977-78. Even though the average during the Fifth Plan had reached 4.9 percent, growth rates during the first three years of the plan averaged less than 4 percent and were characterized by very high variance. Second, though the average growth rate over a whole decade hit the 5 percent mark for the first time during 1980-90, year-to-year growth during this period exhibited considerable fragility.

In particular, the 7.2 percent growth rate in $1980-81$ came on the heels of a 5.2 percent decline in 1979-80. ${ }^{6}$ Consequently, despite the high growth rate in 1980-81, the

\footnotetext{
${ }^{5}$ For example, the first entry in the third column of the table shows the average of the annual growth rates between 1965-66 and 1969-70. To calculate the averages in the first four years in this column, growth rates from years 1965-66 to 1968-69 (not shown in the table) have been used. ${ }^{6}$ Two key factors contributing to the large decline in the net national product in 1979-80: a sever draught, which led to a decline in agricultural production by 12.5 percent, and a large hike in the international price of oil.
} 
level of income at the end of that year was not much higher than that reached two years earlier at the end of 1978-79. Not surprisingly, the average of the growth rates over the ten-year period spanning from 1978-79 to $1987-88$ was an unimpressive 4.1 percent. Anyone looking back at the performance during the preceding 10 years in 1988 would not have been impressed and indeed would have concluded that the economy was still on the Hindu growth path. Even the average of growth rates during the seven-year period from 1981-82 to $1987-88$ at 4.8 percent was below the rate achieved in the Fifth Five Year Plan. It is only when we include the ultra-high growth rates of the last three years of 1980s that the average growth rate from 1981-82 to $1990-91$ jumps to 5.6 percent. The average growth rate over the three-year period from 1987-88 to 1990-91 was a whopping 7.6 percent. Without these three years, there would be no debate on growth during 1980s versus 1990s.

In contrast, growth during the 1990s has been more robust and far less volatile. Following the June 1991 crisis, the annual growth rate quickly picked up and reached the 5.1 percent mark in 1992-93 and never fell below 4.4 percent subsequently. The fiveyear averages of growth rates during 1992-93 to 2001-02 have ranged from 5.5 to 6.7 percent (see the last six entries in the second column of Table 2). This compares with the five-year averages of growth rates ranging from 4.8 to 6.2 percent during 1981-91 and 3.3 to 6.2 percent during $1977-91$.

The fragility of growth in the 1980s relative to that in the 1990s can be seen further in the variances in growth rates of GDP at both the aggregate and sector levels. These variances are shown for some selected five-year periods in Table 3. The lowest 
variance in GDP growth during 1980s shown in Table 3 is 3.16 and relates to the period 1981-86. This figure substantially exceeds those relating to GDP in the post-1992 periods.

To sum up the evidence, the initial break in India's growth rate can be detected in the year 1977-78 when the economy grew at 7.7 percent followed by 5.6 percent in 1978 79. But growth remained fragile and achieved an average of only 4.1 percent over the ten-year period of $1977-78$ to $1987-88$. Growth picked up in a major way only in 198889 when it registered a whopping 10.6 percent rate. It is the average annual growth of 7.6 percent achieved during the three-year period of 1988-91 that largely accounts for the 5.6 percent growth during 1981-91.

As a major outcome of the fragility of growth, the economy crash-landed in 199192 hitting the low growth rate of 0.5 percent. After the July 1991 reform, growth exhibited greater stability, with the growth rate shifting upward by approximately half percent on the average during the 1990s. If we count the crisis years as a part of the 1980s performance and therefore contrast growth experience between 1982-92 and 199202, the growth rates at 5.2 and 6.1 percent, respectively, yield a difference of nearly full percentage point.

The critical question to which I turn next is what accounts for the fragile but significantly higher growth during 1977-91, especially 1988-91, than in the preceding years. While substantially more detailed and quantitative work than done here is required for a full understanding of the determinants of the spurt, two broad factors can be identified. First, liberalization played a significant role. On the external front, policy 
measures such as import liberalization, export incentives and a more realistic real exchange rate contributed significantly to productive efficiency. On the domestic front, freeing up of several sectors from investment licensing reinforced import liberalization and allowed faster industrial growth than in the past. Second, borrowing on the external front allowed investment to be maintained at levels higher than what was possible otherwise and high levels of public expenditures helped boost the economy through the expansion of demand. Unfortunately, the external borrowing and high public expenditures were both unsustainable without deeper structural reforms and therefore carried the seeds of the macroeconomic crisis of 1991 that brought the economy to a grinding halt. $^{7}$

\section{Connection to Liberalization}

To appreciate the role of liberalization in stimulating the pre-1991 growth, it is useful to begin with a brief historical background on import controls in India. In their pioneering study, Bhagwati and Desai (1970) provide the most comprehensive and systematic documentation of the wide sweep of the interventionist policies that had come to exist by late 1960s. As they note, general controls on all imports and exports had been present since 1940. After independence, import controls were relaxed through the

\footnotetext{
${ }^{7}$ In passing, the role of agriculture may also be acknowledged in helping the high growth rates during 1988-91. Though the years 1986-87 and 1987-88 were a disaster for agriculture due to bad weather, the subsequent three years, especially 1988-89, produced unusually high agricultural growth. According to the data in the Economic Survey 2002-03 (Tables 13 and 16), agriculture and allied activities (forestry and logging, fishing, mining and quarrying), which accounted for a
} 
expansion of the Open General Licensing (OGL) list in a stop-go fashion. But a foreign exchange crisis in $1956-57$ put an end to this phase of liberalization and comprehensive import controls were restored and maintained until 1966. In June that year, under pressure from the World Bank, India devalued the rupee from 4.7 rupees to 7.5 rupees per dollar. The 57.5 percent devaluation was accompanied by some liberalization of import licensing and cuts in import tariffs and export subsidies for approximately a year. But by 1968, intense domestic reaction to the devaluation led India to turn inward with vengeance. ${ }^{8}$ Almost all liberalizing initiatives were reversed and import controls tightened. This regime was consolidated and strengthened in the subsequent years and remained more or less intact until the beginning of a period of phased liberalization in the late 1970s.

According to Pursell (1992), the severity of the controls was reflected in a decline in the proportion of non-oil and non-cereals imports in the GDP from the low level of 7 percent in 1957-58 to the even lower level of 3 percent in 1975-76. Since consumer goods imports had been essentially banned, the incidence of this decline was principally borne by machinery, raw material and components. The impact on the pattern of

little more than one third of the GDP, grew at an annual average rate of 7.3 percent during 198891.

${ }^{8}$ Bhagwati and Srinivasan (1975, Chapter 10, p. 153) offer a fascinating political economy analysis of the 1966 devaluation. In a key concluding paragraph, they note, "The political lesson seems particularly pointed with regard to the use of aid as a means of influencing recipient policy, even if, in some objective sense, the pressure is in the 'right' direction. The Indian experience is also instructive for the political timing of devaluation: foreign pressure to change policies, if brought to bear when a government is weak (both because of internal-structural reasons and an impending election, which invariably prompts cautious behavior) can be fatal." 
industrialization and efficiency was visible. Pursell (1992, pp. 433-4) offers a vivid description of the costs to the economy in the following words:

"During this period, import-substitution policies were followed with little or no regard to costs. They resulted in an extremely diverse industrial structure and high degree of self-sufficiency, but many industries had high production costs. In addition, there was a general problem of poor quality and technological backwardness, which beset even low-cost sectors with comparative advantage such as the textiles, garment, leather goods, many light industries, and primary industries such as cotton."

Pursell (1992, p. 434) continues, "Although import substitution reduced imports of substitute products, this was replaced by increased demand for imported capital equipment and technology and for raw materials not domestically produced or in insufficient quantities. During the 1960s and the first half of the 1970s, the former demand was suppressed by extensive import substitution in the capital goods industries and attempts to indigenize R\&D. By about 1976, however, the resulting obsolescence of the capital stock and technology of many industries was becoming apparent, and a steady liberalization of imports of capital equipment and of technology started soon after."

\footnotetext{
${ }^{9}$ Jagdish Bhagwati, who, upon his return from study abroad in the early 1960 s, initially shared in the intellectual attitudes that helped India turn inward but quickly changed his mind in light of the realities on the ground, tells an anecdote that aptly captures the deleterious impact protectionist policies had on the quality of the Indian products. In one of the letters to Harry Johnson, written
} 
Two factors facilitated the emergence of the liberalization phase. First, as already hinted in the above quote from Pursell (1992), by mid 1970s, industrialists themselves were beginning to find the strict regime counterproductive and started pressing the government for the relaxation of controls. A domestic lobby in favor of liberalization of imports of raw materials and machinery had come to exist. At the same time, in the case of raw materials and machinery imports that had no import substitutes, there was no counter lobby. Second, improved export performance and remittances from overseas workers in the Middle East had led to the accumulation of a comfortable level of foreignexchange reserves. This lent confidence to policy makers and bureaucrats who had lived in the perpetual fear of a balance of payments crisis.

Against this background, consider successively the reforms undertaken starting the late 1970s and their impact on the economy.

\subsection{Reforms During Late 1970s and 1980s}

In view of their quiet nature, "liberalization by stealth" is an apt characterization of the pre-1991 reforms. Nevertheless, it gives the misleading impression that these reforms were marginal or inconsequential to the growth performance. The prevailing regime rested on a complex system of licensing but involved no explicit quantitative import restrictions. Therefore, liberalization could be affected merely through a liberal grant of the licenses, without any policy announcements. And given the generally

during his tenure at the Indian Statistical Institute in the early 1960s, Bhagwati happened to complain about the craze he observed in India for everything foreign. Harry Johnson promptly 
protectionist and anti-liberalization ethos in the country, when possible, this is the route Indian politicians chose.

Though the process of relaxation of regulation of industry began in the early 1970s and of trade in late 1970s, the pace of reform picked up significantly only in 1985 with major liberalizing steps taken during the second half of the 1980s. Indeed, as we will see below, during this latter period, the policy had begun to take a somewhat activist form. In turn, the external sector registered a dramatic improvement in the performance. Exports, which had grown annually at a paltry 1.2 percent rate during $1980-85$, registered the hefty annual growth of 14.4 percent during 1985-90 (Table 4). Growth also accelerated significantly during the late 1980s.

Broadly, five liberalizing steps can be identified. First, the OGL list was steadily expanded. Having disappeared earlier, this list was re-introduced in 1976 with 79 items on it. By April 1990 when the import policy covering years 1990-93 was issued, the list came to have 1,339 items on it. In $1987-88,30$ percent of all imports entered under OGL. The inclusion of an item in the OGL list was usually accompanied by an "exemption," which amounted to a tariff reduction. In almost all cases, the items on the list were machinery or raw materials for which no substitutes were produced at home.

The second source of liberalization was the decline in the share of canalized imports. Canalization refers to monopoly rights of the government for the imports of certain items. Between 1980-81 and 1986-87, the share of these imports in total imports 
declined from 67 to 27 percent. Over the same period, canalized non-POL (petroleum, oil and lubricants) imports declined from 44 to 11 percent of the total non-POL imports. This change significantly expanded the room for imports of machinery and raw materials by entrepreneurs. ${ }^{10}$

Third, several export incentives were introduced or expanded, especially after 1985, which helped expand imports directly when imports were tied to exports and indirectly by relaxing the foreign exchange constraint. Replenishment (REP) licenses, which were given to exporters and could be freely traded on the market, directly helped relax the constraints on some imports. Exporters were given REP licenses in amounts that were approximately twice their import needs and, thus, provided a source of input imports for good sold in the domestic market. The key distinguishing feature of the REP licenses was that they allowed the holder to import items on the restricted (and therefore those outside of the OGL or canalized) list and had domestic import-competing counterparts. Even though there were limits to the import competition provided through these licenses, as exports expanded, the volume of these imports expanded as well. This factor became particularly important during 1985-90 when exports expanded rapidly.

In addition to a substantial widening of the coverage of products available to exporters against replenishment licenses, Joshi and Little (1994) list the following export

of the quality of homemade products, the craze for the foreign seemed perfectly rational to him!

${ }^{10}$ The decline in the share of canalized imports was due to increased domestic production of food grains, cotton and crude oil and reduced world prices of canalized imports such as fertilizers, edible oils, nonferrous metals and iron and steel. 
incentives introduced between 1985-86 and 1989-90, referring to them as the "quasiSoutheast Asian style" reforms:

- In the 1985 budget, 50 percent of business profits attributable to exports were made income tax deductible; in the 1988 budget this concession was extended to 100 percent of export profits.

- The interest rate on export credit was reduced from 12 to 9 percent.

- In October 1986, duty-free imports of capital goods were allowed in selected "thrust" export industries. In April 1988, access for exporters to imported capital goods was increased by widening the list of those available on OGL and by making some capital goods available selectively to exporters without going through "indigenous clearance."

- Exporters were given an assurance that the incentives announced in the exportimport policy would not be reduced for a period of three years.

The fourth source of liberalization was a significant relaxation of industrial controls and related reforms beginning in 1985. Several steps are worthy of mention:

- By 1990, 31 industries were completely de-licensed and the investment limit below which no industrial license would be required was raised to Rs. 500 million in backward areas and Rs. 150 million elsewhere, provided the investments were located in both cases at stipulated minimum distances from urban areas of stipulated sizes. Traditionally, the industrial licensing system had applied to all firms with fixed capital in excess of 3.5 million rupees. There remained 27 major industries subject 
to licensing regardless of the size and location of investment. These included a number of major industries like coal, large textile units using power, motor vehicles, sugar, steel and a large number of chemicals. Products subject to Small Scale Industries (SSI) reservation were also off limits though the asset ceiling of firms designated as SSI units was raised from Rs. 2 million to Rs. 3.5 million.

- Broad banding, which allowed firms to switch production between similar production lines such as trucks and cars, was introduced in January 1986 in 28 industry groups. This provision was significantly expanded in the subsequent years and led to increased flexibility in many industries. In some industries, the impact was marginal, however, since a large number of separate product categories remained due to continued industrial licensing in those products.

- In 1986 , firms that reached 80 percent capacity utilization in any of the five years preceding 1985 were assured authorization to expand capacity up to 133 percent of the maximum capacity utilization reached in those years.

- Firms that came under the purview of the Monopolies and Restrictive Trade Practices (MRTP) Act were subject to different rules could not take advantage of the above liberalizing policy changes. To relax the hold of the licensing and capacity constraints on these larger firms, the asset limit above which firms were subject to MRTP regulations was raised from Rs. 
200 million to Rs. 1,000 million and the requirement of MRTP clearances was waived for 27 industries altogether. MRTP firms in a number of industries were exempt from industrial licensing provided they were located 100 kilometers away from large cities. MRTP firms were allowed to avail themselves of the general de-licensing measures in which they were not considered dominant undertakings. These measures significantly enhanced the freedom of large firms (with assets exceeding Rs. 1,000 million) to enter new products.

- Price and distribution controls on cement and aluminum were entirely abolished. Decontrol in cement eliminated black market and through expanded production brought the free-market price down to the controlled levels within a short time. New entrants intensified competition, which led to improvements in quality along with the decline in the price.

- There was a major reform of the tax system. The multi-point excise duties were converted into a modified value-added (MODVAT) tax, which enabled manufacturers to deduct excise paid on domestically produced inputs and countervailing duties paid on imported inputs from their excise obligations on output. By 1990, MODVAT came to cover all sub-sectors of manufacturing except petroleum products, textiles and tobacco. This change significantly reduced the taxation of inputs and the associated distortion. In parallel, a more smoothly graduated schedule of excise tax 
concessions for SSI firms was introduced, which reduced incentives for them to stay small.

The relaxation of industrial controls reinforced the ongoing import liberalization. In the presence of these controls, firms had to have an investment license before they could approach the import-licensing authority for machinery and raw-material imports. For products freed of industrial licensing, this layer of restrictions was removed. More importantly, under industrial licensing, even for products on the OGL, machinery imports were limited by the approved investment capacity and raw material imports by the requirements implied by the production capacity. With the removal of licensing, this constraint was removed.

The final and perhaps the most important source of external liberalization was a realistic exchange rate. At least during the years of rapid growth, there is strong evidence of nominal depreciation of the rupee correcting the overvaluation of the real exchange rate. According to the charts provided in Pursell (1992), both the import-weighted and export-weighted real exchange rates depreciated steadily from 1974-75 to 1978-79 with the approximate decline of the former being 30 percent and of the latter 27 percent. It bears reminding that this was also a period of rapid export expansion (see below) and foreign exchange reserves accumulation that paved the way for import liberalization subsequently. The years 1977-79 also registered the hefty average annual growth of 6.5 percent. The real exchange rate appreciated marginally in the following two years, stayed more or less unchanged until 1984-85 and once again depreciated steadily thereafter. 
Joshi and Little (1994) attribute a considerable part of the success in export expansion during the second half of the 1980 s to the real exchange rate management. Observing that starting in 1986-87, Indian exports grew considerably faster than world trade and as fast as the exports of comparable developing countries, they offer the following assessment (Joshi and Little 1994, Chapter 7, p. 183):

"The real exchange rate was again a critical factor as it depreciated by about 30 percent from $1985 / 86$ to $1989 / 90$. Since Indian inflation in this period rose faster than that of its trading partners, a devaluation of the nominal effective exchange rate of about 45 percent was required and achieved... This reflects a considerable change in the official attitude toward exchange rate depreciation. The change had already begun in 1983, but during 1983 and 1984 action was restricted to keeping the real effective exchange rate constant. From 1985 onward exchange rate policy became more active though the fiction of a fixed basket-peg was still maintained. From a presentational point of view, the sharp devaluation of the U.S. dollar, which began in 1985, helped a great deal. A devaluation of the real effective exchange rate could be secured by keeping the exchange rate or the rupee against the dollar constant, and in fact there was a mild depreciation in terms of the dollar as well. Cabinet approval was sought and obtained to achieve the real effective exchange rate prevailing in 1979 (thus offsetting the competitive disadvantage that had been suffered since then). When that objective had been reached, cabinet approval was again obtained to devalue the rupee further to maintain the competitive relationship vis-à-vis a narrower range of developing-country 
'competitor countries,' many of whom depreciated in real terms along with the U.S. dollar in 1986. This was a sensible exchange rate policy. Policymakers recognized that a real exchange rate devaluation was necessary though the terms of trade were modestly improving, because the debt-service burden had increased and a faster growth of imports was to be expected in the wake of industrial and import liberalization." 11

\subsubsection{Impact of the Reforms}

The impact of reforms could be seen most clearly on trade flows. Pursell (1992, p. 441) states this succinctly and emphatically, "The available data on imports and import licensing are incomplete, out of date, and often inconsistent. Nevertheless, whichever way they are manipulated, they confirm very substantial and steady import liberalization that occurred after 1977-78 and during 1980s." He goes on to note that imports outside of canalization and licensing (i.e., those mainly on the OGL) increased from 5 percent of total imports in 1980-81 to 30 percent in 1987-88. The share of non-POL imports in the remaining imports increased from 8 percent to 37 percent over the same period.

Quite apart from this compositional change, there was considerable expansion of the level of imports during 1970s and the second half of 1980s. Increased growth in exports due to the steady depreciation of the real exchange rate and remittances from the overseas workers in the Middle East had begun to relax the balance of payments

\footnotetext{
${ }^{11}$ This view of the government taking an activist role, shared by the author, is in contrast to the view taken by Srinivasan and Tendulkar (2003, p. 23) as quoted in the introduction.
} 
constraint during the first half of the 1970s, leading to the expansion of non-oil imports at the annual rate of 17.8 percent (Table 4). This rapid expansion continued during the second half of the 1970s with non-oil imports registering an impressive 15 percent annual growth rate over the ten-year period spanning 1970-79. In contrast, in the subsequent five years when the real exchange rate appreciated slightly and the income growth slowed down, non-oil imports expanded only 7.1 percent per annum (Table 4). Again, during 1985-90, they grew 12.3 percent. Thus, liberalized licensing rules flexibly accommodated the increased demand for imports during the fast-growth periods.

Alternatively, the impact of liberalization can be seen in the movement in the imports-to-GDP ratio. Table 5 shows the non-oil imports as a proportion of the GDP. In 1976-77, this ratio had bottomed out at 4.1 percent. Starting in 1977-78, fortuitously the year in which GDP growth showed a break and the real exchange rate depreciated substantially, this ratio began to rise, reaching 5.1 percent in $1980-81$. In the subsequent years, it showed a moderate downward trend reaching 4.8 percent in 1984-85. In 198586, when the Rajiv Gandhi era reforms were kicked off, the ratio began to climb up steadily again until it reached 6 percent in the year 1989-90. This rise is especially important since net national product itself grew at an average annual rate of 6.0 percent during these years.

The expansion of imports was partially achieved through a rapid expansion of exports. During 1985-90, exports grew by 12 percent in US dollar terms and 7 percent in volume terms, well above the growth recorded by world exports of 4 percent in volume terms. The level of exports increased from $\$ 8.9$ billion in $1985-86$ to $\$ 18.5$ billion in 
1990-91, which was only $\$ 4$ billion less than in 1993-94, more than two years after the launch of the July 1991 reform

Citing extensive and systematic evidence, I have argued in Panagariya (2003) that openness is a necessary condition for sustained rapid growth. From the discussion and evidence above, it should be clear that India's pre-1991 experience is no exception to this proposition. We may squabble about the magnitude of trade and industrial liberalization during these years. But it is difficult to overlook the sizable expansion of non-oil exports and imports in the years of high growth without which growth would have been scuttled. The changes in the investment and import licensing policies and the real exchange rate led to considerable response of the industry and trade.

The impact of reforms can also be seen in terms of higher industrial growth. Discussing the changes in the domestic industrial policy, Desai (1999, p. 21) notes, "The changes were complex and arbitrary, but they led to an acceleration of industrial growth from 4.5 per cent in $1985-86$ to a peak of 10.5 per cent in 1989-90." According to the Economic Survey 2002-03 (Table 16), manufacturing, construction, electricity, gas and water supply, which together accounted for a little less than a quarter of the GDP, grew at an average annual rate of 8.9 percent during 1988-91.

According to Goldar and Renganathan (1990), the import penetration ratio in the capital goods sector rose from 11 percent in 1976-77 to 18 percent in 1985-86. This trend appears to have continued subsequently. Malhotra (1992) notes that the incremental capital-output ratio, which had reached as high as 6 at times, fell to approximately 4.5 during 1980 s. These observations are consistent with the finding by 
Joshi and Little (1994) that the productivity of investment increased during 1980s, especially in private manufacturing.

Bur more systematically, Chand and Sen (2002) have recently studied the relationship between trade liberalization and productivity in manufacturing using 3-digit industry data spanning 1973-88 econometrically. They take 30 industries, which accounted for 53 percent of gross value added and 45 percent of employment in manufacturing over this period. These industries divide approximately equally among consumer, intermediate and capital goods. They measure protection by the proportionate wedge between the Indian and U.S. price and estimate total factor productivity growth (TFPG) in the three industry groups averaged over three non-overlapping periods: 197478, 1979-83 and 1984-88. They then relate this productivity growth to liberalization.

Table 8 presents the findings of Chand and Sen (2002, Table 3). Consistent with the discussion in the previous subsection, according to their measure also, protection declines over the sample period in intermediate and capital goods sectors but not consumer goods sector. Moreover, there is a significant improvement in TFPG in all three sectors in 1984-88 compared with the two earlier periods. Thus, the jump in TFPG coincides with the liberalization in capital and intermediate goods.

Chand and Sen (2002) do some further tests by pooling their sample and employing fixed-effects estimator to allow for intrinsic differences across industries with respect to the rate of technological progress. Their estimates show that on average one percentage point reduction in the price wedge leads to 0.1 percent rise in the total factor productivity. For the intermediate goods sector, the effect is twice as large. The impact of the 
liberalization of the intermediate goods sector on productivity turns out to be statistically significant in all of their regressions.

\section{Unsustainable External Borrowing and Public Expenditure}

But the liberalization of industry and trade tell only a part of the story. Another factor responsible for the rapid growth during the pre-1991 era was borrowing abroad and rising government expenditures at home.

The external borrowing helped bridge the considerable gap between exports and imports. Despite faster growth in exports than imports in the second half of 1980 s, due to a sizable initial gap, the absolute difference between imports and exports remained large. Based on the RBI trade data on the balance of payments accounts, which differ significantly from the customs (DGCIS) data, total imports-to-GDP ratio exceeded the total exports-to-GDP ratio by 2.5 to 3 percentage points throughout the $1980 \mathrm{~s}^{12}$ Accordingly, the higher level of imports was financed partially through external borrowing.

Viewed another way, during 1985-90, on average, gross domestic savings and investment were 20.4 and 22.7 percent of the GDP, respectively. With foreign investment being negligible and annual foreign aid staying unchanged at approximately $\$ 400$ million through much of the decade, it was largely foreign borrowing that made up the difference between savings and investment.

\footnotetext{
${ }^{12}$ Imports such as offshore oilrigs and defense expenditures that do not go through the customs but do enter the balance of payments presumably account for the discrepancy.
} 
While foreign borrowing, thus, helped the economy achieve a higher rate of investment and imports, it also led to a rapid accumulation of foreign debt, which rose from 20.6 billion dollars in 1980-81 to $\$ 64.4$ billion in 1989-90 (Joshi and Little, 1994, p. 186). The accumulation was especially rapid during the second half of the decade with long-term borrowing rising from the annual average of $\$ 1.9$ billion during $1980-81$ to 1984-85 to $\$ 3.5$ billion from 1985-86 to $1989-2000$. Moreover, “other” capital flows and errors and omissions turned from a large negative figure in the first half of the decade into a positive figure indicating an increase in the short-term borrowing in the latter period. The external-debt-to-GDP ratio rose from 17.7 percent in 1984-85 to 24.5 percent in 1989-90. Over the same period, the debt-service ratio rose from 18 to 27 percent.

The growth in debt was also accompanied by a rapid deterioration in the "quality" of debt between 1984-85 and 1989-90. The share of private borrowers in the total longterm debt increased from 28 to 41 percent. The share of non-concessional debt rose from 42 to 54 percent. The average maturity of debt declined from 27 to 20 years. Thus, while external debt was helping the economy grow, it was also moving it steadily towards a crash.

A similar story was also evolving on the internal front. While external borrowing helped relieve some supply side constraints, rising current domestic public expenditures provided the stimulus to demand, particularly in the services sector. Joshi and Little 
(1994), as also Srinivasan and Tendulkar (2003), assign much of the credit for the growth during 1980 s to this demand-side factor. Defense spending, interest payments, subsidies and the higher wages following the implementation of the Fourth Pay Commission recommendations fueled these expenditures. Table 7 , which reproduces Table 7.5 in Joshi and Little (1994), documents the magnitude of the expansion of current government expenditures at the center and state levels combined during the second half of the 1980s. During the first half of the 1980s, these expenditures averaged 18.6 percent. In the second half, they rose to average 23 percent with the bulk of the expansion coming from defense, interest payments and subsidies, whose average rose from 7.9 to 11.2 percent of the GDP.

As with the external borrowing, high current expenditures proved unsustainable. They manifest themselves in extremely large fiscal deficits. As Table 7 shows, combined fiscal deficits at the central and state levels, which averaged 8 percent in the first half of the 1980 s went up to 10.1 percent in the second half. Continued large deficits of this magnitude led to a build up of very substantial public debt with interest payments accounting for a large proportion of the government revenues. They also inevitably fed into the current account deficits, which kept rising steadily until they reached 3.5 percent of the GDP and 43.8 percent of exports in 1990-91. The eventual outcome of these developments was the June 1991 crisis. 


\section{Summing up}

I have argued that the growth spurt prior to 1991 was fragile and volatile. There was a jump in the growth rate during 1977-79, massive decline in 1979-80, a jump again in 1980-82, return to the Hindu rate during 1982-88 except 1983-84, climb up again in 1988-91 and crisis in 1991-92. This volatility in the growth pattern itself raises doubts about the sustainability of a 5 percent plus growth rate over long haul. The 1991 crisis only confirmed the fundamental weakness of the underlying forces ex post.

In contrast, growth during 1990s has been more robust, exhibiting far less volatility. Whereas in the late 1980s, many observers of India were betting on a crisis any time, there are few takers of such a bet today. Despite well-known vulnerabilities resulting from fiscal deficits that are as large today as in the late 1980s and slow pace of banking reforms, few pundits are predicting an external crisis today. The external-debtto-GDP ratio has been declining and foreign-exchange reserves at approximately $\$ 90$ billion exceed the currency in circulation. Indeed, in a recent careful examination of India's vulnerability to external crises, Ahluwalia (2002) points to several key weaknesses in fiscal and banking areas and emphasizes the urgency of tackling them. But he stops well short of predicting a crisis. Since reforms have continued in spite of many hiccups and are likely to continue in the future and since the dynamic, fast-growing information technology sector is poised to grow into a sizable proportion of the economy in the coming years, long-term-growth prospects can get only better.

At the same time, significantly higher average rate of growth during the 1980s relative to that in the preceding decades was not achieved without important policy 
changes. In contrast to the isolated ad hoc policy measures taken to release immediate pressures prior to $1980 \mathrm{~s}$, the measures in the last half of $1980 \mathrm{~s}$, taken as a whole, constituted a significant change and an activist reform program. For example, by 1990, approximately 20 percent of the tariff lines and 30 percent of the imports had come under OGL with significant exemptions on tariffs accruing to the OGL products. This compares with an additional 45 percent tariff lines being freed from import licensing and the highest tariff brought down from to 150 percent. ${ }^{13}$ As regards industrial licensing, 31 sectors had already been freed from it by 1990 with 27 sectors remained subject to it. The 1991 reform abolished industrial licensing for all except a select list of hazardous and environmentally sensitive industries. Prior to 1990, significant liberalizing steps had also been taken towards freeing up the large-sized firms by raising the asset limit defining the MRTP firms five fold and opening a number of avenues for the license-free entry of MRTP firms in many sectors. The 1991 reform did away with the MRTP restrictions altogether. Seen this way, the 1980s reforms and their success provided crucial first-hand evidence to policy makers that gradual liberalization can deliver faster growth without causing disruption. In turn this evidence gave policy makers confidence in taking somewhat bolder moves in the July 1991 budget.

\footnotetext{
${ }^{13}$ There is a tendency on the part of the analysts such as Das (2000) to ignore the changes made in the 19980s and attribute them to the July 1991 reform. When one considers the facts that 20 percent of the tariff lines were already under OGL, that another 30 plus percent tariff lines including all consumer and agricultural goods were not freed until the end of 1990s and the top tariff line was still 110 percent, the July 1991 reform was not as sweeping as it may seem.
} 
While the changes in the 1980 s were undoubtedly small in relation to those in the 1990s, they were quite significant when compared with the regime prevailing until the 1970s. In part, this fact explains why the economy, particularly industrial growth, exhibited such as strong response. A key message of the theory of distortions is that the larger the initial distortion, the greater the benefit from its relaxation at the margin. Therefore, the large response to limited reforms is quite consistent with at least the static theory of distortions. One suspects that under plausible assumptions, this result would translate into larger growth responses to larger initial distortions in the endogenous growth models. In this respect, DeLong's observation that the elasticity of growth to reforms was higher in the 1980s than in the 1990s is not altogether inconsistent with theory, though it must be acknowledged that the response would have been short-lived in the absence of more concerted reforms.

DeLong's contention that we lack hard evidence to support the view that rapid growth of the second half of the 1980s could not be sustained without the second wave of reforms in the 1990s is untenable. I have argued that pre-1991 growth was itself fragile and sporadic. And even then, it ended in a balance of payments crisis. The scenario of the second half of 1980s involving large amounts of external borrowing could not have been sustained. Absent that, more substantial reforms that improved efficiency, brought foreign investment to the country and allowed sectors such as information technology to grow constituted the only way to avoid the return to the Hindu rate of growth of the first 30 years of independence. 


\section{Looking Ahead: Why India Lags behind China}

There remain skeptics inside and outside India who argue that more substantial liberalization of the external sector has not resulted in a significant improvement in the performance of that sector. They argue that export growth during 1990s has not been much higher than that achieved during 1980s when the level of protection was much higher.

Evidence on the relative performance of the external sector during 1980s and 1990s bellies the skeptics, however. Exports of goods and services grew at an annual rate 10.7 percent during 1990s compared with 7.4 percent during 1980s. Likewise, imports grew at 9.7 percent during 1990s compared with 5.9 percent during 1980s. The annual growth rate of exports as well as imports has, thus, risen by 3.3 percentage points.

This rise has manifested itself in a significant increase in the imports-to-GDP and exports-to-GDP ratios. On the export side, the ratio approximately doubled from 7.3 percent to 14 percent between 1990 and 2000 and on the imports side it jumped from 9.9 percent to 16.6 percent. The overall trade to GDP ratio has thus gone up from 17.2 percent in 1990 to 30.6 percent in 2000. In contrast, the change in the trade-to-GDP ratio between 1980 and 1990 was smaller: from 15.2 percent to 17.2 percent. $^{14}$

On the foreign investment front, India has been receiving approximately $\$ 5$ billion every year since $1994-95$ compared with just $\$ 0.1$ billion during 1990-91. This amount is split approximately equally between foreign direct investment (FDI) and 
portfolio investment. ${ }^{15}$ There has also been a significant shift in the remittances from abroad: from $\$ 2.1$ billion in 1990 to $\$ 12.3$ billion in 2000 .

While the basic claim of the skeptics is thus readily refuted, it must be acknowledged that the response of the external sector to liberal trade and investment policies has been an order of magnitude weaker in India than China. Exports of goods and services grew at annual rates of 12.9 and 15.2 percent during 1980s and 1990s respectively in China. Imports exhibited a similar performance. Consequently, China's total trade to GDP ratio rose from 18.9 percent in 1980 to 34 percent in 1990 and to 49.3 percent in 2000 .

On the foreign investment front, differences are even starker. FDI into China has risen from $\$ .06$ billion in 1980 to $\$ 3.49$ billion in 1990 and then to a whopping $\$ 42.10$ billion in 2000. China was slower to open its market to portfolio investment but once it did, inflows quickly surpassed those into India, reaching $\$ 7.8$ billion in 2000 . Even if we allow for an upward bias in the figures as suggested by some China specialists and downward bias in the figures for India, there is little doubt that foreign investment flows into China are several times those into India.

While some differences between the performances of India and China can be attributed to the Chinese entrepreneurs in Hong Kong and Taiwan, who have been eager to escape rising wages in their respective home economies by moving to China, a more

\footnotetext{
${ }^{14}$ As I have already argued, the major change during 1980s was concentrated in the last few years so that the total movement during the decade taken as a whole was limited.

${ }^{15}$ As is now well known, these figures understate foreign investment since they do not include investments of profits by existing foreign firms.
} 
central explanation lies in the differences between the compositions of GDPs in the two countries. Among developing countries, India is unique in having a very large share of its GDP in the mostly informal part of the services sector. Whereas in other countries, a decline in the share of agriculture in GDP has been accompanied by a substantial expansion of the industry in the early stages of development, in India this has not happened. For example, in 1980, the proportion of GDP originating in the industry was 48.5 percent in China but only 24.2 percent in India (Table 8). Services, on the other hand, contributed only 21.4 percent to GDP in China but as much as 37.2 percent in India.

In the following twenty years, despite considerable growth, the share of industry did not rise in India. Instead, the entire decline in the share of agriculture was absorbed by services. Though a similar process was observed in China, the share of industry in GDP was already quite high there. As a result, even in 2000, the share of services in GDP was 33.2 percent in China compared with 48.2 percent in India.

Why does this matter? Because typically, under liberal trade policies, developing countries are much more likely to be able to expand exports and imports if a large proportion of their output originates in industry. Not only is the scope for expanding labor-intensive manufactures greater, a larger industrial sector also requires imported inputs thereby offering greater scope for the expansion of imports. In India, the response of imports has been just as muted as that of exports. This is demonstrated by the fact that recently RBI has had to purchase huge amounts of foreign exchange to keep the rupee from appreciating. And even then, it was unsuccessful and had to let the currency 
appreciate 5 to 7 percent in nominal terms. Imports have simply failed to absorb the foreign exchange generated by even modest foreign investment flows and remittances.

This same factor is also at work in explaining the relatively modest response of FDI to liberal policies. Investment into industry, whether domestic or foreign, has been sluggish. Foreign investors have been hesitant to invest in the industry for much the same reasons as the domestic investors. At the same time, the capacity of the formal services sector to absorb foreign investment is limited. The information technology sector has shown promise but its base is still small. Moreover, this sector is more intensive in skilled labor than physical capital.

Therefore, the solution to both trade and FDI expansion in India lies in stimulating growth in industry. The necessary steps are now common knowledge: bring all tariffs down to 10 percent or less, abolish the small-scale industries reservation, institute an exit policy and bankruptcy laws and privatize all public sector undertakings. The real question is: will the government move swiftly or haltingly? 
References

Ahluwalia, Montek, 2002a, "Economic reforms in India since 1991: Has Gradualism Worked?," Journal of Economic perspectives 16(3), 67-88.

Ahluwalia, Montek, 2002b, "India's Vulnerability to External Crises," in Ahluwalia, M., Y. V. Reddy and S. S. Tarapore, Macroeconomics and Monetary Policy: Issues for a reforming Economy, New Delhi: Oxford university Press, Chapter 9, 183214.

Bhagwati Jagdish and Padma Desai, 1970, India: Planning for Industrialization, London: Oxford University press.

Bhagwati, Jagdish and T. N. Srinivasan, 1975, Foreign Trade Regimes and Economic Development: India, New York: National Bureau of Economic Research.

Chand, Satish and Kunal Sen, 2002, "Trade Liberalization and Productivity Growth: Evidence from Indian Manufacturing," Review of Development Economics 6, No. $1,120-32$.

Das, Gurchuran, 2000, India Unbound: A Personal Account of a Social and Economic Revolution (New York: Knopf: 037541164X).

DeLong, J. Bradford, 2001, "India Since Independence: An Analytic Growth Narrative," in Dani Rodrik, ed., Modern Economic Growth: Analytical Country Studies (forthcoming).

Desai, Ashok, 1999, "The Economics and Politics of Transition to an Open Market Economy: India,” OECD Working Papers, Volume VII, No. 100. 
Goldar B and V S Renganathan (1990), "Liberalization of Capital Goods Imports in India," Working Paper No. 8, National Institute of Public Finance and Policy, New Delhi.

Joshi, Vijay and I. M. D. Little, 1994, India: Macroeconomics and Political Economy: 1961-91, Washington, DC: World Bank.

Malhotra, R. N., 1992, "Economic reforms: Retrospect and Prospects," ASCI Foundation Day Lecture, Administrative Staff College of India, Hyderabad.

Panagariya, Arvind, 1990, "Indicative Planning in India: Discussion," Journal of Comparative Economics 14, 736-742.

Panagariya, Arvind, 1994, "India: A New Tiger on the Block?" Journal of International Affairs, Vol. 48, No. 1, pp. 193-221.

Panagariya, Arvind, 2003, "Miracles and Debacles: Do free Trade Skeptics have a Case?" http://www.bsos.umd.edu/econ/panagariya/apecon/polpaper.htm

Pursell, Garry, 1992, “Trade Policy in India," in Dominick Salvatore, ed., National Trade Policies, New York: Greenwood Press, 423-458.

Rodrik, Dani, 2002, “Institutions, Integration, and Geography: In Search of the Deep determinants of Economic Growth," in Dani Rodrik, ed., Modern Economic Growth: Analytical Country Studies (forthcoming).

Srinivasan and Tendulkar, 2003, Reintegrating India with the World Economy, Washington DC: Institute for International Economics.

Virmani, Arvind, 1997, "Economic development and Transition in India." Paper presented at the Tokyo Dialogue on Alternatives to the World Bank-IMF 
Approach to Reforms and Growth, Economic Planning Agency, Tokyo, Japan, November 7. 
Table 1: Average Annual Growth Rates by Plans at Constant 1993-94 Prices (percent)

\begin{tabular}{|c|c|c|}
\hline PERIOD & $\begin{array}{l}\text { Gross Domestic Product at } \\
\text { Factor Costs }\end{array}$ & $\begin{array}{c}\text { Per-capita Gross Domestic Product } \\
\text { at Factor Costs }\end{array}$ \\
\hline \multicolumn{3}{|l|}{ ACCORDING TO FIVE-YEAR PLANS } \\
\hline FIRST PLAN (1951-56) & 3.6 & 1.8 \\
\hline SECOND PLAN (1956-61) & 4.3 & 2.3 \\
\hline THIRD PLAN (1961-66) & 2.8 & 0.6 \\
\hline THREE ANNUAL PLANS (1966-69) & 3.9 & 1.7 \\
\hline FOURTH PLAN (1969-74) & 3.4 & 1.1 \\
\hline FIFTH PLAN (1974-79) & 4.9 & 2.6 \\
\hline ANNUAL PLAN (1979-80) & -5.2 & -7.7 \\
\hline SIXTH PLAN (1980-85) & 5.6 & 3.5 \\
\hline SEVENTH PLAN (1985-90) & 6.0 & 3.8 \\
\hline TWO ANNUAL PLANS (1990-92) & 3.4 & 1.4 \\
\hline EIGHTH PLAN (1992-97) & 6.7 & 4.7 \\
\hline NINTH PLAN (1997-2002) & 5.5 & 3.6 \\
\hline \multicolumn{3}{|l|}{ ACCORDING TO DECADES } \\
\hline $1951-61$ & 3.9 & 2.0 \\
\hline $1961-71$ & 3.8 & 1.5 \\
\hline 1971-81 & 3.2 & 0.9 \\
\hline 1981-91 & 5.6 & 3.5 \\
\hline 1991-01 & 5.7 & 3.7 \\
\hline \multicolumn{3}{|l|}{ Memo } \\
\hline $1951-74$ & 3.6 & 1.5 \\
\hline $1977-91$ & 5.1 & 2.9 \\
\hline 1992-02 & 6.1 & 4.1 \\
\hline
\end{tabular}


Table 2: Annual Growth Rates

\begin{tabular}{|c|c|c|c|}
\hline \multirow[b]{2}{*}{ Year } & \multirow[b]{2}{*}{ Actual } & Average of Five Years & Average of Ten Years \\
\hline & & Ending with the Year* & Ending with the Year** \\
\hline $1969-70$ & 6.5 & 2.9 & 4.0 \\
\hline $1970-71$ & 5.0 & 4.7 & 3.8 \\
\hline $1971-72$ & 1.0 & 4.7 & 3.5 \\
\hline $1972-73$ & -0.3 & 3.0 & 3.3 \\
\hline $1973-74$ & 4.6 & 3.4 & 3.2 \\
\hline $1974-75$ & 1.2 & 2.3 & 2.6 \\
\hline $1975-76$ & 9.0 & 3.1 & 3.9 \\
\hline $1976-77$ & 1.2 & 3.1 & 3.9 \\
\hline $1977-78$ & 7.5 & 4.7 & 3.8 \\
\hline $1978-79$ & 5.5 & 4.9 & 4.1 \\
\hline $1979-80$ & -5.2 & 3.6 & 2.9 \\
\hline $1980-81$ & 7.2 & 3.2 & 3.2 \\
\hline $1981-82$ & 6.0 & 4.2 & 3.7 \\
\hline $1982-83$ & 3.1 & 3.3 & 4.0 \\
\hline $1983-84$ & 7.7 & 3.7 & 4.3 \\
\hline $1984-85$ & 4.3 & 5.6 & 4.6 \\
\hline $1985-86$ & 4.5 & 5.1 & 4.2 \\
\hline $1986-87$ & 4.3 & 4.8 & 4.5 \\
\hline $1987-88$ & 3.8 & 4.9 & 4.1 \\
\hline
\end{tabular}




\begin{tabular}{llll}
\hline $1988-89$ & 10.5 & 5.5 & 4.6 \\
$1989-90$ & 6.7 & 6.0 & 5.8 \\
$1990-91$ & 5.6 & 6.2 & 5.6 \\
$1991-92$ & 1.3 & 5.6 & 5.2 \\
$1992-93$ & 5.1 & 5.8 & 5.4 \\
$1993-94$ & 5.9 & 4.9 & 5.2 \\
$1994-95$ & 7.3 & 5.0 & 5.5 \\
$1995-96$ & 7.3 & 5.4 & 5.8 \\
$1996-97$ & 7.8 & 6.7 & 6.1 \\
$1997-98$ & 4.8 & 6.6 & 6.2 \\
$1998-99$ & 6.5 & 6.7 & 5.8 \\
$1999-00$ & 6.1 & 6.5 & 5.8 \\
$2000-01(\mathrm{PE})$ & 4.4 & 5.9 & $\mathbf{5 . 7}$ \\
$2001-02(\mathrm{QE})$ & 5.6 & $\mathbf{5 . 5}$ & $\mathbf{6 . 1}$ \\
\hline
\end{tabular}

*For example, the first entry in this column shows the average of the growth rates over 1965-70. To calculate the averages in the first four years in this column, growth rates from years 1965-69 have been used as appropriate but not shown. Figures in bold type indicate growth rate for a Five-Year Plan.

** For example, the first entry in this column shows the average of the growth rates over 1960-70. To calculate the averages in the first nine years in this column, growth rates from years 1960-69 have been used as appropriate but not shown. Figures in bold type indicate growth rate for decades such as the 1960s, 1970s, etc.

PE, QE: Provisional Estimate and Quick Estimate, respectively.

Source (Tables 1 and 2): Economic Survey, 2002-03, Table 12 and the author's calculations 
Table 3: Five-yearly Variance of Growth Rates: Major Sectors and GDP

\begin{tabular}{lcccc}
\hline Year & Agriculture & Industry & Services & GDP \\
\hline $1976-81$ & 110.53 & 32.58 & 4.20 & 28.42 \\
$1981-86$ & 17.21 & 4.17 & 1.15 & 3.16 \\
$1986-91$ & 46.90 & 3.75 & 1.07 & 7.01 \\
$1987-92$ & 49.08 & 28.63 & 2.24 & 11.66 \\
$1991-96$ & 11.87 & 42.28 & 4.00 & 6.09 \\
$1992-97$ & 14.17 & 14.88 & 2.92 & 1.29 \\
$1997-02$ & 15.60 & 2.93 & 2.61 & 0.79 \\
$1998-03$ & 17.19 & 3.05 & 1.62 & 0.96 \\
\hline
\end{tabular}


Table 4: Average Annual Growth Rates of Non-oil Merchandise Exports and Imports in Current Dollars

\begin{tabular}{lcc}
\hline Year & Exports & Imports \\
\hline $1970-71$ to $1974-75$ & 16.2 & 17.8 \\
$1975-76$ to $1979-80$ & 13.7 & 12.3 \\
$1980-81$ to $1984-85$ & 1.2 & 7.1 \\
$1985-86$ to $1989-90$ & 14.4 & 12.3 \\
\hline
\end{tabular}

Source: Author's calculations from the data in RBI Statistical Handbook, 2001 (Table 115). RBI cites its source as the Directorate General of Commercial Intelligence and Statistics (DGCIS). 
Table 5: Merchandise non-oil exports and imports as percent of GDP

\begin{tabular}{ccc}
\hline Year & $\begin{array}{c}\text { Non-oil Exports as } \\
\text { Percent of GDP }\end{array}$ & $\begin{array}{c}\text { Non-oil Imports as } \\
\text { Percent of GDP }\end{array}$ \\
\hline $1970-71$ & 3.3 & 3.3 \\
$1971-72$ & 3.3 & 3.3 \\
$1972-73$ & 3.6 & 3.1 \\
$1973-74$ & 3.8 & 3.7 \\
$1974-75$ & 4.3 & 4.3 \\
$1975-76$ & 4.8 & 4.9 \\
$1976-77$ & 5.7 & 4.1 \\
$1977-78$ & 5.3 & 4.4 \\
$1978-79$ & 5.2 & 4.7 \\
$1979-80$ & 5.3 & 4.9 \\
$1980-81$ & 4.7 & 5.1 \\
$1981-82$ & 4.5 & 5.0 \\
$1982-83$ & 4.0 & 4.6 \\
$1983-84$ & 3.7 & 5.0 \\
$1984-85$ & 4.0 & 4.8 \\
$1985-86$ & 3.7 & 5.3 \\
$1986-87$ & 3.9 & 5.6 \\
$1987-88$ & 4.2 & 5.1 \\
$1988-89$ & 4.7 & 5.7 \\
$1989-90$ & 5.5 & 6.0 \\
\hline
\end{tabular}

Source: Calculated from data on exports, imports, GDP and exchange rates in the RBI Statistical Handbook, 2001. RBI cites its source of the trade data as the Directorate General of Commercial Intelligence and Statistics DGCIS. 
Table 6: Changes in Protection and Total Factor Productivity Growth (TFPG) by Industry Classification (unweighted averages)

\begin{tabular}{lccc}
\hline Industry Classification & $\begin{array}{c}\text { Consumer } \\
\text { Goods }\end{array}$ & $\begin{array}{c}\text { Intermediate } \\
\text { Goods }\end{array}$ & Capital Goods \\
\hline Protection: (percent change) & & & -1.8 \\
$1974-78$ & 4.5 & 0.4 & 1.7 \\
$1979-83$ & -1.1 & 1.4 & -4.3 \\
$1984-88$ & -0.4 & -5.4 & \\
TFPG (percent) & & & -1.6 \\
$1974-78$ & -0.5 & -1.2 & -1.5 \\
$1979-83$ & -1.2 & -3.1 & 3.7 \\
$1984-88$ & 5.1 & 4.8 & \\
\hline
\end{tabular}

Source: Chand and Sen (2002) 
Table 7: Fiscal Indicators: 1980-81 to 1989-90

(As percent of GDP)

\begin{tabular}{|c|c|c|c|c|c|c|c|c|}
\hline & Average & & & & & & & Average \\
\hline & $1980-81$ to & & & & & & & $1985-86$ to \\
\hline & $1984-85$ & $1985-86$ & 1986-87 & $1987-88$ & 1988-89 & $1989-90$ & $1990-91$ & $1989-90$ \\
\hline Revenue & 18.1 & 19.5 & 20 & 20.1 & 19.6 & 20.9 & 19.5 & 20 \\
\hline Current expenditure & 18.6 & 21.4 & 22.6 & 23.1 & 22.7 & 24.8 & 23.9 & 23 \\
\hline Defense & 2.7 & 3.3 & 3.8 & 4 & 3.8 & 3.6 & - & 3.7 \\
\hline Interest & 2.6 & 3.3 & 3.6 & 4 & 4.2 & 4.6 & 4.8 & 3.9 \\
\hline Subsidies* & 2.6 & 3.3 & 3.4 & 3.5 & 3.6 & 4.2 & - & 3.6 \\
\hline Capital expenditure & 7.5 & 7.4 & 8.3 & 7 & 6.3 & 6.5 & 6 & 7.1 \\
\hline Total expenditure & 26.1 & 28.8 & 30.9 & 30.1 & 29 & 31.3 & 29.9 & 30.1 \\
\hline Fiscal deficit & 8 & 9.3 & 10.9 & 10 & 9.4 & 10.4 & 10.4 & 10.1 \\
\hline
\end{tabular}

*CSO Estimates.

Source: Government of India, Ministry of Finance (various issues) Indian Economic Statistics--Public Finance [Joshi and Little (1994, Table 7.5)] 
Table 8: Composition of GDP (Percent) 198019902000

China

$\begin{array}{llll}\text { Agriculture } & 30.1 \quad 27 & 15.9\end{array}$

$\begin{array}{llll}\text { Industry } & 48.5 & 41.6 & 50.9\end{array}$

Manufacturing $\quad 40.5 \quad 32.9 \quad 34.5$

$\begin{array}{llll}\text { Services } & 21.4 & 31.3 & 33.2\end{array}$

India

$\begin{array}{llll}\text { Agriculture } & 38.6 & 31.3 & 24.9\end{array}$

$\begin{array}{llll}\text { Industry } \quad 24.2 & 27.6 & 26.9\end{array}$

$\begin{array}{llll}\text { Manufacturing } \quad 16.3 & 17.2 & 15.8\end{array}$

$\begin{array}{llll}\text { Services } & 37.2 & 41.1 & 48.2\end{array}$

Source: World Bank, Basic indicators 